\title{
RESEARCHING LEAN: METHODOLOGICAL IMPLICATIONS OF LOOSE DEFINITIONS
}

\author{
MIKAEL BRÄNNMARK, JOSTEIN LANGSTRAND, STINA \\ JOHANSSON, AGNETA HALVARSSON, LENA ABRAHAMSSON, \\ JÖRGEN WINKEL
}

\section{INTRODUCTION}

The use of Lean-related methods and practices is currently common in the Swedish manufacturing sector. Lean-inspired change programs have also become increasingly common in healthcare, construction, and service (e.g. SALAR, 2012; Arlbjørn et al., 2011; Börnfelt, 2006; Johansson and Abrahamsson, 2009).

Some researchers argue that Lean is similar to other management concepts, such as Total Quality Management (TQM) and Six Sigma Quality (e.g., Dahlgaard and Dahlgaard-Park, 2006) or learning organizations (Hines et al., 2004). Other researchers have noted similarities between Lean and TQM although they still argue that these approaches are conceptually different (e.g., Pettersen, 2009). Despite an extensive amount of Lean research, presently there is no consensus on how to define Lean; researchers and practitioners disagree on both its nature and content (Pettersen, 2009; Shah and Ward, 2007; Golhar and Stamm, 1991; Hines et al., 2004).

As demonstrated by Pettersen (2009), there is considerable variation in the scientific and grey literature on Lean; the concept is described as either a philosophy, a toolbox, a strategic goal or a change process. Rather than focusing on a single property, Pettersen argues that Lean can be seen as a multidimensional concept that comprises all of these aspects. Furthermore, Hines et al. (2004) claim that Lean has changed over time, from specific shop-floor practices to a more general concept, and further to the more abstract and vague 'Lean thinking'. This observation resonates with the finding that Total Quality Management has moved from rational to normative control (Giroux, 2006), making it similar to many other management concepts (Barley and Kunda, 1992). This variation is likely caused by several factors, such as influence from a variety of stakeholders (researchers, practitioners, management consultants, gurus, etc.) and other management concepts, trends and the zeitgeist (Kieser, 1997; Giroux, 2006).

The conceptual fluctuation of Lean has important methodological consequences for research. First, to better understand the impact of Lean, the Lean interventions must be described in detail; this is rarely the case in existing 
studies, e.g., in studies of musculoskeletal disorders from Lean-inspired work systems (Brännmark et al., 2012). Consequently, it becomes difficult to assess and understand what type of organizational activities that are performed under the Lean banner. General principles, such as 'customer focus' or 'just in time', can have multiple meanings, even within the same organization (Alvesson et al., 2008, Langstrand, 2012). Thus, we need a better understanding of what organizations actually $d o$ when they do Lean.

When studying the effects of Lean, several non-Lean factors need to be considered. These factors can potentially have a greater impact on the outcome of the change initiative than the operationalized concept itself. These factors include implementation design, leadership style and worker participation (Landsbergis et al., 1999; Brännmark et al., 2012, Westgaard and Winkel, 2011), institutional factors (e.g., union strength and national legislation regarding working conditions; Hampson, 1999), the relationship between management, unions and personnel (Bruno and Jordan, 2002; Hasle et al., 2012), important stakeholders' interpretations of the Lean concept (Langstrand, 2012), the work life sector (Shah and Ward, 2003), product life cycle, innovative capability and product characteristics (e.g., volume and customer adaptation (Fullerton et al., 2003; Berggren, 1993), the organization's starting point in terms of levels of change competence, dynamics, or rigidity, hierarchy and internal boarders, and equality and interaction (Abrahamsson, 2002).

To better understand Lean and its potential impact on various outcomes, theoretical and methodological clarifications are needed. This applies to the concept itself, the causal link between Lean and organizational outcomes, and the mediating factors mentioned above. Such clarifications do not, however, imply the need for a definition of Lean. Instead, research into the effects of Lean must be capable of handling the varying and often vague nature of the concept; simply relying on general labels, e.g., Lean Production, is insufficient (Landsbergis et al., 1999). Although some attempts have been made in this regard (e.g. Hasle et al., 2012, Genaidy and Karwowski, 2003; Westgaard and Winkel, 2011), this area still requires more research.

\section{OBJECTIVE}

This paper aims to further clarify some key methodological issues that need to be considered in order to draw conclusions about the effects of loosely defined management concepts such as Lean.

\section{METHOD}

\subsection{A case study approach}

The five case studies creating the empirical basis for this paper all consist of analyses of Lean operationalizations in different contexts. Details regarding the 
methodological approach of each case study may be retrieved from previous publications referred to below.

The included case studies have not been designed or performed specifically for this paper. However, all the cases are located in Sweden, although the local context, the rationale for adopting Lean, and the type of organization varied. As a consequence, the original research purpose, design, and methods for data collection vary. To handle this variation, a number of methodological considerations were taken as part of the analysis performed for this paper. These considerations aimed to reduce the negative impact of variation in the original case study designs and data collection strategies.

A conceptual framework for steering the subsequent analysis in this paper was created. The theoretical background for this framework was multi-disciplinary, although it is influenced by management fashion theory (e.g., Benders and Van Veen; 2001, Abrahamson, 1996), neo-institutional theory (e.g., Brunsson, 2009; Røvik, 2000), and translation theory (e.g., Langstrand, 2012). The theoretical framework comprised the following four categories:

1) Influential Lean models for the operationalization of Lean in the specific case study (if this information were available, i.e., general ideals);

2) Aims and goals of the Lean initiatives as perceived by the initiating organizations in the case study (i.e., the local ideals);

3) Operationalization of Lean in the case studies (e.g., Lean tools, methods, and strategies); and

4) Implementation strategies used in the case studies.

This framework aims to create a basis for making cross case analyses of recurring patterns and possible inconsistencies across the cases. Hence the framework illustrated the variability in interpretations and operationalization of Lean between the studied organizations, allowing the framework to some degree to use a replication logic in the case studies (Yin, 1993).

A careful selection of case studies was made to ensure a sufficient amount of information on each category of the framework. The selection was based on those available to the researchers in existing or forthcoming publications.

\subsection{Data extraction}

Information from the case studies was extracted to form an empirical basis for the subsequent analysis. This was achieved by transforming the conceptual framework into a cross-case matrix (Miles and Huberman, 1994) that encapsulated the various elements of each category (Table 1).

The case descriptions (see Results) formed the basis for the cross-case matrix (Table 1). First, the paper authors responsible for each previous study 
summarized the findings of the studies based on the four categories in the theoretical framework (above). These summations were purposely limited in length and made up the basis for the case descriptions (see Results).

Second, based on the case descriptions, one of the paper authors made the first extraction of data from these summations for the cross-case matrix. The other authors then assessed the results of this process. Through consensus, the design of the matrix and the included categories in each case study were then updated.

\subsection{Analysis strategy}

Based on the four categories described above, the case studies were first analysed for internal consistency. The local ideals were compared to two existing influential Lean ideals, i.e., the models proposed by Liker (2004) and Womack and Jones (2003). While there are many other descriptions of Lean, these two seem to be the most influential models, based on their citation rate (Pettersen, 2009). Therefore, they served as good reference models for the local ideals used in each case study included in this paper.

The operationalization (i.e., the choice of Lean principles, practices, and techniques) was compared to the local ideals and the espoused goals of the Lean initiative. The implementation strategies were compared to the elements of the operationalization.

In the second stage of the analysis, the case studies were compared and contrasted with respect to the four categories of the framework. Any differences and common aspects of the local ideals, operationalization, and implementation strategies were analysed. The outcome of these discussions formed the basis for the categories presented in the Discussion section of this paper.

\section{RESULTS}

\subsection{Case study 1: a Swedish national Lean program (Brännmark, 2010, Brännmark and Eklund, forthcoming)}

The Swedish national program named Produktionslyftet (The Production Leap) aims at supporting medium sized manufacturing companies in their Lean implementation processes. Rationale for the program is that Swedish industry is losing its competitiveness against other countries, e.g., low cost manufacturing nations. Hence, they must become more effective to survive. According to the program's inspiration seminars in 2009, the solution is to adopt Lean Manufacturing. In terms of Lean, the program representatives are heavily inspired by Liker's (2004) description of Lean in his book The Toyota Way.

To assist the companies in their Lean implementation process, a heavily subsidized change program was used. Produktionslyftet aims at recruiting companies with a management commitment to Lean. The selected companies are then supported by an extensive consulting approach, consisting of university 
courses, coaching in Lean techniques and methods, as well as other related methods (e.g., change management and quality management). Commonly used Lean tools are, with some exceptions, housekeeping through $5 \mathrm{~S}$, improvement groups, value stream mapping, standardization, and methods for set-up time reduction. All companies also develop and document their interpretation of a Lean philosophy.

The implementation design is similar to classical project management. For example, Lean coordinators are appointed, operative steering groups are formed, and pilot projects are initiated for most of the work. However, several of the Lean tools are often integrated into the implementation design, e.g., pilot projects based on value stream mapping or improvement groups being used to introduce and maintain new Lean tools. The program tries to create a broad commitment in the company for Lean through methods such as Lean Lego Games. This approach aims to include companies. However, the program has (during the program period 2010-2012) become more normative, prescribing to a higher degree what the companies should do (e.g., what Lean tools they should select).

\subsection{Case study 2: a large Swedish manufacturing company (Langstrand, 2012, Langstrand and Elg, 2012)}

HiTech Inc. (a pseudonym) produces, sells, and services complex machinery for industrial applications. The company is located in central Sweden, and the main site has approximately 2000 employees, which makes HiTech one of the largest companies in the region.

In 2003, the corporate head of production introduced the use of Lean. During a series of discussions with the production manager at HiTech, they agreed on a number of principles that would form the basis for their Lean initiative: standards, continuous improvement, teamwork, levelled workload, and takted production flow (i.e., a production pace in sync with customer demand).

The HiTech management team felt that they did not have the capacity to drive the change process on their own. Therefore, a Lean coordinator was brought in as an advisor and an external consultant was invited to assist the management team.

Assisted by the consultant, an implementation plan was designed. According to this plan, HiTech would initiate the change process by implementing a few basic methods - 5S and Visual Management - and use these as a base for successively implementing other methods associated with the Lean concept.

Early in the process of introducing Lean, the management team realized a need to create reference areas to test Lean principles. This led to a pilot project in one of the production units. The project was initiated with a value stream mapping, which was performed during 2005. Based on the results of this analysis, a project plan was designed with the aim of introducing kanban and of reducing the leadtime and production cost within the unit. A project team was installed to manage and monitor the project. 
The change has been managed as a typical top-down process. All the managers received extensive training in Lean, but the operators only received general information about the concept.

\subsection{Case study 3: an union approach to Lean (Johansson, forthcoming)}

IF Metall organizes 350,000 workers within different sectors in the Swedish industry where Lean production is found to be the leading management concept. The trade union recognizes the need for an effective industry in order to maintain and increase the competiveness of Swedish industry, which in return secures their members' employment. To ensure that the implementation of Lean does not deteriorate their members' working conditions, they actively participate in the implementation process.

The concept of Sustainable Work (IF Metall, 2010) provides guidelines for trade union representatives. Here the focus is to develop the work organization, to increase work content, and to develop more work, which in return will lead to motivating workers to engage in the development of the company. In order to achieve this win-win situation, partnership between employer and trade union is stressed, a tactic also found in Produktionslyftet or in the on-going European Social Fund project Sustainable Development and Competitive Strength (Johansson, forthcoming)

The Sustainable Development and Competitive Strength project includes nine companies from two regions. Many, but not all, strive to implement Lean production, in some cases obtained through participation in Produktionslyftet. The goal of the project is to increase productivity and enlarge the work content through development of the work organization. These goals are mainly obtained through the use of work rotation and new or enlarged roles on the shop floor, initially implemented in pilot groups. Competence development is a significant part of the project, for example, in leadership, tutoring, and team building. Fulfilling the customers' needs is a foundation for the participating companies, which becomes visible in project plans, for example, expressed as a need to obtain flexible organizations. It is, however, not found as a part of the overall goal of the project.

The project is based on the idea of partnership on three levels (central, regional, and local) where steering groups consisting of participants from different trade unions and management representatives own the change process at each company. Local change leaders/Lean coaches or trade union representatives are responsible for implementation and are supported by an external coach with deep knowledge in development processes. They try to adapt this new way of working to the companies' existing values, visions, and strategic plans.

\subsection{Case study 4: a Swedish municipality (Brännmark et al., 2011)}

A medium sized municipality currently runs a program to introduce Lean in its welfare section. The program's rationale is that less money will flow into the system due to demographic changes. Future pensioners may also have different 
needs than today's pensioners. The program is influenced by the Swedish program Verksamhetslyftet, which is a national Lean education program catering to the public sector.

The implementation of Lean is designed and executed by a support team consisting of two Lean leaders and a number of Lean coaches recruited within the organization. The program, an initiative of the director of the social welfare department, aims to use Lean thinking to increase efficiency, to provide appropriate service for care takers and clients, and to make better use of employees' existing competencies and skills. The Lean support team is monitored by the top management steering group, but up until now the Lean support group has been rather self-steered, answering only to the director of the social welfare department and the chief executive of Social Welfare development.

In the implementation phase, along with massive promotion work from top management and the support team, all managers on all levels are educated and trained in Lean philosophy and a set of Lean tools. Each work unit is then supported by Lean coaches. Value stream mapping is the first and most commonly used tool, often followed by the introduction of improvement groups. Other tools such as structured methods for problem solving, 5S (for housekeeping), and visualization are used on a smaller scale. The introduction of Lean is made in a similar way with the support from the Lean coaches in all work units. After the initial months, the units can choose more freely how to adopt Lean. However, the units are required to use Lean as a method to improve work performance.

\subsection{Case study 5: medium sized manufacturing companies (Abrahamsson, 2009, 2002)}

Case 5 is a longitudinal study of eight large and medium sized industrial companies (pulp and paper, electronics, and food) attempting to implement something that can be described as a modern organization. The first study was conducted between 1994 and 1998. Although the studied projects were not referred to as Lean, they had a clear inspiration from the first wave of Lean and they combined this with the ideas of learning organization and flow organization.

The projects aimed to achieve better product quality and organizational effectiveness by creating production flows from order to customer. The main approaches were $5 \mathrm{~S}$ and shorten lead times by removal of bottlenecks in production. In addition, much of the discussions addressed how to focus on core processes, continuous improvements, and flexibility. The project also presented more concrete strategies such as job rotation, self-managing teams, and delegating white-collar work tasks to blue-collar workers. The companies also refurbished machines to follow the flow organization. An important part of the projects was the introduction of different internal courses designed to broaden the skills of the employees, to encourage co-creation, to support changed readiness, and to develop a sense of ownership among all employees. It was a clear top- 
down approach, but all the companies made their implementation projects in cooperation with the unions and in a positive spirit in order to do good for both the company and its employees. Despite this, the organizational changes proved difficult to implement and the change processes were characterized by problems and restoring responses.

The follow-up study (2004-2005) included return visits to three of the previously studied companies (two pulp and paper and one electronics) and their change projects. The organization projects that the companies now were working with were to a high degree a continuation or rather a reboot of the change projects they had been working on ten years earlier, but now the projects were named so as to include the word 'Lean'. The projects contained different types and combinations of the usual tools and elements of Lean, but also organizational ideas, for example, cross-functional process teams. In this way, the companies were examples of the second wave of Lean. This follow-up study showed that some of the restoring responses found in the first study were temporary and the companies now implemented parts of what they were talking about ten years earlier.

\section{DISCUSSION}

\subsection{Methodological limitations}

The use of multiple case studies based on varying research design presents several issues when assuming replication logic, i.e., to compare multiple cases.

The study design, data collection strategy, and analysis methods differed in the original publications. Furthermore, the nature of the publications also varied: peer reviewed papers, conference papers, book chapters, doctoral theses, etc. While the conceptual framework offers some means to handle this variation, this issue still suggests limitations in the comparability of the cases.

Because one researcher performed the initial classifications of the cases, there was a risk for coding bias. This issue, however, has been at least partly handled by the consensus discussion used to update the matrix.

There is much variation in how these cases use the Lean concept, a fact that is arguably the result of the ambiguous nature of the Lean concept. This variation could also be the result of the selection processes for the case studies in the paper. However, the included cases have not been selected to maximize case variation; instead, they were selected to illustrate prevailing variation in some mainstream Swedish Lean processes used today.

In general, these methodological issues suggest that the validity of the comparison of case studies may be somewhat limited. However, the cases were included for illustrative purposes. Therefore, since the limitations mostly apply to the external validity of the cases, the methodological implications of these limitations may be restricted. 


\subsection{Analysis and comparison of the cases}

A comparison of the cases shows that they share a similar Lean rhetoric; some form of perceived outside threat creates a need to increase efficiency. The expected effects of Lean are also similar. However, when reducing the level of abstraction in the analysis, the variation across the cases increases in terms of how Lean is interpreted and operationalized. This increase in variation does not, however, seem to apply to implementation design; rather, it seems to be relatively homogenous across the cases. This may not be surprising given that it mostly conforms to classic project management models and methods (Winter et al., 2006).

Table 1 - Comparison of cases

\begin{tabular}{|c|c|c|c|c|c|}
\hline & Case 1 & Case 2 & Case 3 & Case 4 & Case 5 \\
\hline \multicolumn{6}{|l|}{ Local ideal } \\
\hline External threat & 0 & 0 & 0 & 0 & $\odot$ \\
\hline Value generation & - & $\odot$ & - & - & \\
\hline Increased efficiency & $\boldsymbol{0}$ & - & $\boldsymbol{0}$ & 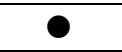 & 0 \\
\hline Higher motivation & $\odot$ & $\odot$ & $\boldsymbol{0}$ & & $\bullet$ \\
\hline Improved working conditions & $\mathrm{O}$ & $\odot$ & 0 & & 0 \\
\hline Systems thinking & 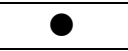 & 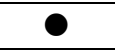 & 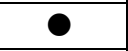 & 0 & $\boldsymbol{0}$ \\
\hline Influence of gurus (e.g., Liker) & 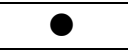 & 0 & $\odot$ & $\odot$ & \\
\hline Customer satisfaction & $\odot$ & & $\odot$ & 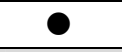 & \\
\hline \multicolumn{6}{|l|}{ Operationalization } \\
\hline Value stream mapping & 0 & - & $\odot$ & 0 & • \\
\hline $5 \mathrm{~S}$ & 0 & 0 & $\odot$ & $\mathrm{O}$ & $\mathbf{0}$ \\
\hline Standardization & 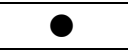 & $\mathrm{O}$ & & & 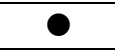 \\
\hline Just in time/Kanban & $\mathrm{O}$ & 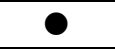 & & & • \\
\hline Setup time reduction & 0 & & & & 0 \\
\hline Visual management & $\mathrm{O}$ & 0 & & $\mathrm{O}$ & $\boldsymbol{0}$ \\
\hline \multicolumn{6}{|l|}{ Implementation } \\
\hline Values and culture & 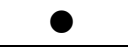 & - & 0 & 0 & • \\
\hline Improvement teams & • & - & - & 0 & 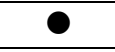 \\
\hline Steering groups & - & - & - & - & $\mathrm{O}$ \\
\hline Consultant support & $\boldsymbol{0}$ & $\odot$ & $\bullet$ & $\odot$ & $\bullet$ \\
\hline Lean coordinators & 0 & 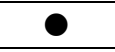 & $\mathrm{O}$ & 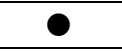 & \\
\hline Pilot projects & $\mathbf{0}$ & 0 & - & & $\odot$ \\
\hline Education/courses & 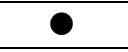 & 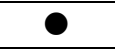 & 0 & $\odot$ & 0 \\
\hline Active ownership & $\odot$ & $\mathrm{O}$ & $\odot$ & 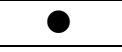 & \\
\hline Local adaptation of concept & $\odot$ & 0 & & 0 & \\
\hline
\end{tabular}


When comparing these results to the models proposed by Liker (2004) and Womack and Jones (2003), there are noticeable similarities as well as differences. Operationally, the studied cases seem mostly influenced by Womack and Jones' model, exemplified by the wide-ranging use of value stream mapping. These results are similar to studies of common tools and approaches used in Lean Healthcare and Lean applications in municipalities (Poksinska, 2010; Mazzocato et al., 2010; Brännmark, 2012; Arlbjørn et al., 2011). Apart from value stream mapping, there are few similarities between the case studies. Even within similar contexts there is substantial variation in the operationalization of Lean.

Both Liker (2004) and Womack and Jones (2003) share a similar rhetoric. They argue that Lean will create the most efficient organizations, while simultaneously providing better jobs and increased customer satisfaction. In fact, Womack et al. (1991) argues that the widespread adoption of Lean will lead to a better world. Clear traces of this rhetoric are evident in all of the included case studies, albeit with some variation. For instance, in the case of the national program Produktionslyftet (case 1), the importance of industrial competitiveness is stressed, whereas the importance of creating good jobs and sustainable work systems are emphasized in the union case (case 3). These differences plausibly reflect the different perspectives of the different stakeholders, e.g., the unions focus on working conditions. However, the common theme is still a need for increased efficiency although the espoused reasons for this vary among the case studies.

Consequently, based on the included case studies and the comparison to the most popular Lean ideals, there are reasons to argue that the main theme in these case studies are organizations seeking ways to become more efficient although for differing reasons. Given the significant variation in the operationalization of Lean, the mere fact that they all label their change programs as Lean tells us little about their actual contents. Methodologically, this variation has at least three implications.

First, if we are to understand what these organizations actually do as part of their Lean programs, we need to describe the Lean interventions in much more detail. Simply relying on the label Lean tells us little about the contents of the interventions. This also applies to our understanding of the causal link between Lean programs and specific effects on the studied organizations.

Second, the large variation in the operationalization of Lean implies that the external validity could suffer in studies that lack a detailed description of the Lean interventions. Hence, more vague and general descriptions of Lean that rely on Lean principles or analogies (e.g. 'learning organizations'; Hines et al., 2004) - are not a viable research strategy for handling the vagueness of the Lean concept. Conversely, a more rigorous methodology including detailed descriptions of the context, implementation design, and operationalization of Lean would arguably provide a more suitable strategy for doing research on loosely defined concepts such as Lean. 
Third, the case studies also emphasized the need for future research on mediating factors for the impact of Lean programs. In the case studies, there are large contrasts in some of the contextual factors mentioned above in terms of the initiators of the change program, the type of organization, and type and degree of participation in the change process. Previous studies suggest that these factors may strongly affect the outcome of Lean change programs. However, more research is needed to evaluate their mediating strength.

\section{REFERENCES}

Abrahamson, E. (1996), "Management Fashion", The Academy of Management Review, 21, pp. 254-285.

Abrahamsson, L. (2002), "Restoring the order: gender segregation as an obstacle to organisational development", Applied Ergonomics, 33, pp. 549-557.

Abrahamsson, L. (2009), Att återställa ordningen: könsmönster och förändring $i$ arbetsorganisationer, Umeå, Borea.

Alvesson, M., Sveningsson, S. and Torhell, S.-E. (2008), Förändringsarbete $i$ organisationer: om att utveckla företagskulturer, Malmö, Liber.

Arbjørn, J. S., Freytag, P. V. and De Haas, H. (2011), "Service supply chain management: A survey of lean application in the municipal sector", International Journal of Physical Distribution \& Logistics Management, 41, pp. 277-295.

Barley, S., R and Kunda, G. (1992), "Design and Devotion: Surges of Rational and Normative Ideologies of Control in Managerial Discourse", Administrative Science Quarterly, 37, pp. 363-399.

Benders, J. and Van Veen, K. (2001), "What's in a Fashion? Interpretative Viability and Management Fashions". Organization, 8, pp. 33-53.

Berggren, C. (1993), "Lean Production - The End of History?", Work, Employment and Society, 7, pp. 163-188.

Bruno, R. and Jordan, L. (2002), "Lean Production and the Discourse of Dissent", Working USA, 6, pp. 108-134.

Brunsson, N. (2009), Reform as routine: organizational change and stability in the modern world, Oxford, Oxford University Press.

Brännmark, M. (2010), "Implementering av Lean i medelstora företag - En lärande utvärdering om hållbar utveckling”, HELIX Working Papers (10/4), Linköping University. Retrieved from http://www.divaportal.org/smash/get/diva2:460012/FULLTEXT01

Brännmark, M. (2012), “Lean i kommuner och myndigheter - en översikt över existerande empirisk forskningslitteratur". Innovationsrådet (2011:42), Stockholm. Retrieved from http:/www.innovationsradet.se/wp/wpcontent/uploads/2012/02/Forskningsoversikt-lean.pdf 
Brännmark, M. and Eklund, J. (forthcoming), "Lean-inspirerade förändringsprogram och personalens upplevelser av dessa", In: SEDERBLAD, P. (ed.) Japanska Produktionssystem och Lean Production. Liber: Stockholm.

Brännmark, M., Eklund, J., Håkansson, M. and Vogel, K. (2012), "Belastningsergonomiska studier utifrån ett produktions- och systemperspektiv interventioner, verksamhetseffekter och konsekvenser", Arbetsmiljöverket, Stockholm. Retrieved from

http://www.av.se/dokument/aktuellt/kunskapsoversikt/RAP2012_01.pdf

Brännmark, M., Halvarsson, A. and Lindskog, P. (2011), "Implementing Lean in Swedish Municipalities and Hospitals - Initial effects on the work system", Presented at the conference Forum för arbetslivsforsknings konferens (FALF2011): Det nya arbetslivet, Luleå, Sweden. Retrieved from http://www.diva-portal.org/smash/get/diva2:460019/FULLTEXT01

Börnfelt, P.-A. (2006), "Förändringskompetens på industrigolvet: kontinuerligt förändringsarbete $\mathrm{i}$ gränslandet mellan lean production och socioteknisk arbetsorganisation”, Doctoral thesis, Institutionen för arbetsvetenskap Göteborgs universitet; Arbetslivsinstitutet. Retrieved from https://gupea.ub.gu.se/bitstream/2077/4379/1/ah2006_01.pdf.

Dahlgaard, J., J and Dahlgaard-Park, S. M. (2006), "Lean production, six sigma quality, TQM and company culture", The TQM Magazine, 18, pp. 263-281.

Fullerton, R. R., McWatters, C. S. and Fawson, C. (2003), "An examination of the relationships between JIT and financial performance". Journal of Operations Management, 21, pp. 383-404.

Genaidy, A. M. and Karwowski, W. (2003), "Human performance in lean production environment: Critical assessment and research framework", Human Factors and Ergonomics in Manufacturing and Service Industries, 13, pp. 317330.

Giroux, H. (2006), “'It Was Such a Handy Term': Management Fashions and Pragmatic Ambiguity*", Journal of management studies, 43, pp. 1227-1260.

Golhar, D. Y. and Stamm, C. L. (1991), "The just-in-time philosophy: A literature review", International Journal of Production Research, 29, pp. 657 676.

Hampson, I. (1999), "Lean Production and the Toyota Production System Or, the Case of the Forgotten Production Concepts", Economic and Industrial Democracy, 20, pp. 369-391.

Hasle, P., Bojesen, A., Jensen, P. L. and Bramming, P. (2012), "Lean and the working environment - a review of the literature", International Journal of Operations and Production Management, 32, pp. 829-849

Hines, P., Holweg, M. and Rich, N. (2004), "Learning to evolve: A review of contemporary lean thinking", International Journal of Operations and Production Management, 24, pp. 994-1011. 
IF Metall (2010), "Hållbart arbete - en plattform för utveckling av arbetsorganisationen". IF Metall, Retrieved from:

http://www.ifmetall.se/ifmetall/home/resources.nsf/vRes/if_metall_12995809187 18_hallbart_arbete_webb_pdf/\$File/H\%C3\%A51lbart\%20arbete_webb.pdf

Johansson, J. and Abrahamsson, L. (2009), "The good work - A Swedish trade union vision in the shadow of lean production", Applied Ergonomics, 40, pp. 775-780.

Johansson, S. (forthcoming). "Svenska fackföreningarna och lean - ett tudelat förhållande", in: SEDERBLAD, P. (ed.) Japanska Produktionssystem och Lean Production. Stockholm: Liber.

Kieser, A. (1997), "Rhetoric and Myth in Management Fashion", Organization, 4, pp. 49-74.

Landsbergis, P. A., Cahill, J. and Schnall, P. (1999), "The impact of lean production and related new systems of work organization on worker health", Journal of Occupational Health Psychology, 4, pp. 108-30.

Langstrand, J. (2012), "Exploring organizational translation : a case study of changes toward Lean Production", Doctoral thesis, Department of Management and Engineering, Linköping University. Retrieved from: http://liu.divaportal.org/smash/get/diva2:503206/FULLTEXT03

Langstrand, J. and Elg, M. (2012), "Non-human resistance in changes towards Lean", Journal of Organizational Change Management, 25, pp. 853-866.

Liker, J. K. (2004), The Toyota way: 14 management principles from the world's greatest manufacturer, New York, McGraw-Hill.

Mazzocato, P., Savage, C., Brommels, M., Aronsson, H. and Thor, J. (2010), "Lean thinking in healthcare: a realist review of the literature", Quality and Safety in Health Care, 19, pp. 376-382.

Miles, M. B. and Huberman, A. M. (1994), Qualitative data analysis : an expanded sourcebook, Thousand Oaks, CA, Sage.

Pettersen, J. (2009), "Defining Lean Production - some conceptual and practical issues", The TQM Journal, 21, pp. 127 - 142.

Poksinska, B. (2010), "The Current State of Lean Implementation in Health Care: Literature Review", Quality Management in Healthcare, 19, pp. 319-329.

Røvik, K. A. (2000), Moderna organisationer: trender inom organisationstänkandet vid millennieskiftet, Malmö, Liber.

SALAR (2012), "Lean - Motiv, initiativ, implementering och resultat", Swedish Association of Local Authorities and Regions, Retrieved from: http://brs.skl.se/brsbibl/kata_documents/doc40182_1.pdf

Shah, R. and Ward, P. T. (2003), "Lean manufacturing: context, practice bundles, and performance", Journal of Operations Management, 21, pp. 129-149. 
Shah, R. and Ward, P. T. (2007), "Defining and developing measures of lean production", Journal of Operations Management, 25, pp. 785-805.

Westgaard, R. H. and Winkel, J. (2011), "Occupational musculoskeletal and mental health: Significance of rationalization and opportunities to create sustainable production systems - A systematic review", Applied Ergonomics, 42, pp. 261-296.

Winter, M., Smith, C., Morris, P. and Cicmil, S. (2006), "Directions for future research in project management: The main findings of a UK government-funded research network", International Journal of Project Management, 24, pp. 638649.

Womack, J. and Jones, D. (2003), Lean thinking: banish waste and create wealth in your corporation, London, Free Press Business.

Womack, J., P., Jones, D., T. and Roos, D. (1991), The machine that changed the world : The story of lean production, New York, Harper Perennial.

Yin, R. K. (1993), Applications of case study research, Newbury Park, Calif., Sage.

\section{ABOUT THE AUTHORS}

Mikael Brännmark, Ph.D. Student, Royal Institute of Technology (KTH), Division of Ergonomics, Stockholm, Sweden, Linköping University, HELIX VINN Excellence Centre, Linköping, Sweden, e-mail: mikael.brannmark@sth.kth.se

Jostein Langstrand, Lecturer, Ph.D., Linköping University, Division of Quality Technology and Management, Linköping, Sweden, Linköping University, HELIX VINN Excellence Centre, Linköping, Sweden,

e-mail: jostein.langstrand@liu.se

Stina Johansson, Ph.D. Student, Luleå University of Technology, Department of Human Work Science, Luleå, Sweden, e-mail: stina.johansson@ltu.se

Agneta Halvarsson, Ph.D. Student, Linköping University, HELIX VINN Excellence Centre, Linköping, Sweden, APeL FoU, Örebro, Sweden, e-mail: agneta.halvarsson@apel-fou.se

Lena Abrahamsson, Professor, Ph.D., Luleå University of Technology, Department of Human Work Science, Luleå, Sweden, e-mail: lena.abrahamsson@1tu.se

Jörgen Winkel, Professor, Dr. Med. Sc., University of Gothenburg, Department of Sociology and Work Science, Göteborg, Sweden and Technical University of Denmark, Department of Management Engineering, Lyngby, Denmark, e-mail: jorgen.winkel@gu.se 